\title{
PERSEPSI MAHASISWA FISIP UNIVERSITAS SUMATERA UTARA MENGENAI NETIKET DI DUNIA MAYA ${ }^{1}$
}

\author{
Yovita Sabarina Sitepu \\ Universitas Sumatera Utara \\ Jl. dr. T. Mansur, Medan \\ v1ta711@yahoo.com
}

\begin{abstract}
Abstrak: Sebagai pengguna internet (netizen), tidak jarang kita merasa kesal saat pengguna lain mentautkan nama kita pada iklan bisnisnya, ataupun beriklan di dinding akun kita. Selain itu, tidak jarang kita menemukan perang komentar di situs berita online yang pada akhirnya merembet ke urusan agama, suku ataupun golongan tertentu. Etiket bergaul di dunia maya tidak ubahnya dengan yang di dunia nyata. Di Indonesia, untuk situs jejaring sosial Facebook, penggunanya didominasi remaja usia 18-24 tahun. Dan biasanya selain memiliki akun Facebook, mereka juga memiliki akun Twitter dan rajin membaca berita di situs berita online. Berangkat dari fenomena tersebut, penelitian ini ingin melihat bagaimana pengetahuan dan penerapan Netiket (etiket di dunia maya) pada mahasiswa FISIP USU. Dari 302 responden, hanya 47 responden yang pernah mendengar netiket, dan hanya 37 responden yang dapat menjawab dengan benar apa itu netiket. 185 responden menyatakan "sangat setuju" dan 113 responden menyatakan "setuju" bahwa netizen harus menerapkan netiket. 3 orang responden menyatakan "tidak setuju" dan 1 orang responden menyatakan "sangat tidak setuju".
\end{abstract}

Kata Kunci: Persepsi, Netiket, Netizen, Mahasiswa FISIP USU

\begin{abstract}
As an internet user (netizen), we often feel irritated when there is an advertisement posted onto our wall without any permission or we are tagged into an ads. Otherwise, we always see comments war that spread into ethnic, religion and certain group issues. What we should/should not do in cyber world is the same with what we should/should not do in the real life. In Indonesia, Facebookers mostly comes from the adolescent aged between 18 to 24 years old. They are not only have a facebook account but also twitter and often read online news. This research aims to know the knowledge and the perception of FISIP USU students about netiquette. Only 47 of 302 have heard about netiquette, and only 37 respondents can answer what netiquette is correctly. 185 respondents say "strongly agree" and 113 respondents say "agree" that netizen should obey the netiquette. 3 respondents say "not agree" and 1 respondent says "strongly not agree".
\end{abstract}

Key Words: Perception, Netiquette, Netizen, FISIP USU Students

\section{Pendahuluan}

Saat ini kita hidup di dunia yang tanpa batas. Tanpa batas di sini maksudnya adalah kita bisa berhubungan dengan orang lain dari belahan dunia manapun tanpa ada penghalang ruang (geografis) dan waktu. Pagi, siang, ataupun malam, kita tetap bisa berkomunikasi dengan orangorang yang memiliki kesukaan yang sama dengan kita. Hal itu semua menjadi mungkin karena keberadaan internet.

1 Penelitian dilakukan dengan melibatkan mahasiswa sebagai tenaga lapangan. Mereka adalah Farida Hanim S.Sos., Munzaimah Masril, S.Sos., dan Firman Frans Silalahi. 
Internet adalah singkatan dari interconnection networking, yaitu sistem global dari jaringan komputer yang saling terhubung dengan menggunakan standar Internet Protocol Suite (TCP/IP). Vincent Cerft dan Robert E. Kahn mengembangkan internetworking protocol yang kemudian berkembang menjadi TCP/IP (Consalvo and Ess, 2011).

Sejak kemunculan internet pada tahun 1994, telah banyak aspek kehidupan manusia yang berubah. Internet mengubah cara kita menulis, bekerja, hidup, bahkan cara berpikir kita. Bertahun-tahun kemudian sejak kehadiran internet, kini muncul berbagai situs jejaring sosial (social networking site) yang juga menggunakan koneksi internet dalam pengoperasiannya. Adapun beberapa situs jejaring sosial yang saat ini tengah digandrungi oleh netizen (sebutan bagi pengguna internet), antara lain: Facebook, Twitter, LinkedIn, Google+, MySpace, dan lain sebagainya.

Saat ini situs jejaring sosial seperti Facebook, memiliki 500 juta pengguna aktif, dan sekitar 70\% pengguna Facebook berasal dari luar Amerika Serikat. Indonesia sendiri merupakan negara keempat terbesar dalam penggunaan Facebook. Tiap tahun angka pengguna akun ini semakin meningkat. Bahkan saat ini angka tersebut melebihi 42 juta akun, yang mana artinya hampir 95\% pengguna internet di Indonesia memiliki akun Facebook. Komposisi pengguna Facebook di Indonesia masih didominasi oleh remaja usia 18-24 tahun (www.checkfacebook.com).

Ketika kita berkomunikasi di dunia maya (di media sosial, forum, dan sebagainya), di mana kita tidak bertatapan langsung (face to face) dengan lawan bicara, kita merasa tidak perlu mengedepankan kesopanan dan kepatutan dalam berkomunikasi. Kita merasa berbicara dengan mesin, dengan sesuatu yang tidak jelas, riil atau tidak, sehingga tidak ada 'wajah' yang harus dijaga.

Padahal seringkali dinyatakan bahwa karena komunikasi online menawarkan anonimitas, maka diharapkan keterbukaan dan kejujuran yang lebih dibanding komunikasi tatap muka. Di samping itu, anonimitas juga menyebabkan terjadinya bentuk-bentuk komunikasi yang kurang menarik, seperti flaming, trolling (tindakan yang secara sengaja membuat user lain emosi, frustrasi, dsb), cyberstalking (memata-matai), dan cyber-bullying (Ess, 2009:5)

Data di Dewan Pers pada tahun 2011 menunjukkan, jenis media yang banyak mendapat pengaduan dari masyarakat akibat melakukan pelanggaran adalah media cetak, media siber, dan media elektronik. Persoalannya adalah, jumlah pengaduan terhadap media siber ini meningkat $100 \%$ dari tahun 2010, dari 13\% (19 pengaduan) menjadi 26\% (43 pengaduan) di tahun 2011 (Sudibyo, 2012). 
Salah satu contoh kasus yang terjadi di situs jejaring sosial adalah kasus 4 murid SMU Negeri Tanjungpinang yang dikeluarkan dari sekolah akibat menghina guru mereka. Pangkal persoalannya sepele, karena keempat murid tersebut kesal dengan tugas yang diberikan oleh guru bidang keterampilan tersebut. Mereka menumpahkan kekesalannya di Facebook dan menyinggung kondisi guru tersebut yang belum menikah (menyebut 'perawan tua'). Guru yang merasa tersinggung akhirnya melaporkan tindakan keempat murid tersebut, yang ia anggap telah menghina/melecehkan dirinya (news.detik.com).

Selain contoh di atas, bagi kita yang sering berselancar di dunia maya, tidak jarang menemukan komentar yang bernada melecehkan dan berbau SARA, baik itu di situs jejaring sosial maupun forum berita online. Seperti contoh saat membaca berita olahraga tentang $E l$ Classico antara Barcelona melawan Real Madrid, tidak jarang ada pengunjung yang berkomentar dengan menyebutkan "Bancilona" ataupun "Madridusta". Dengan mem-posting komentarkomentar yang berbau kebencian itu, tentu saja bisa memicu perselisihan di dunia nyata.

Masih banyak persoalan lain yang ditimbulkan akibat kegagapan pengguna jejaring sosial. Pemberitaan mengenai anak perempuan yang hilang atau kabur dari rumah setelah berkenalan dengan seseorang di dunia maya, berkali-kali menghiasi layar kaca kita. Jika dilihat dari data bahwa pengguna akun jejaring sosial didominasi oleh remaja, maka tidak mengherankan karena anak-anak di usia tersebut seringkali masih berada dalam kondisi labil.

Pengetahuan mengenai etika di dunia maya (netiket) haruslah dimiliki oleh orang-orang yang menghabiskan banyak waktunya di dunia maya. Karena, sama halnya dengan dunia nyata, etika menjadi panduan kita apa yang boleh dan tidak boleh dilakukan ketika kita berhubungan dengan orang lain. Berdasarkan uraian tersebut, peneliti tertarik untuk melihat bagaimana persepsi mahasiswa FISIP Universitas Sumatera Utara (USU) mengenai netiket di dunia maya.

\section{Perumusan Masalah}

Rumusan masalah dalam penelitian ini adalah "bagaimana persepsi mahasiswa FISIP Universitas Sumatera Utara (USU) mengenai netiket di dunia maya?”

\section{Tujuan Penelitian}

Tujuan dari penelitian ini adalah untuk menemukan gambaran mengenai bagaimana pengetahuan dan penerapan netiket dalam pergaulan di dunia maya pada mahasiswa FISIP 
Universitas Sumatera Utara. Pergaulan di dunia maya mencakup di jejaring sosial facebook, microblogging Twitter, serta forum berita online.

\section{Kerangka Pemikiran}

Penelitian ini menggunakan teori mengenai etika di dunia maya atau netiket, serta teori mengena persepsi. Aspek dari persepsi yang akan dianalisis, yaitu:

1. Perhatian (atensi)

- Faktor eksternal penarik perhatian.

- Faktor internal penaruh perhatian.

- Faktor sosiopsikologis

2. Faktor Fungsional

- Kerangka rujukan

3. Faktor-faktor struktural

- Konteks

- Kedekatan/persamaan

Aspek dari netiket yang akan dianalisis, yaitu:

1. Pengetahuan responden mengenai netiket

2. Penerapan netiket oleh responden ketika berselancar di dunia maya.

Persepsi Mahasiswa FISIP USU

Netiket

1. Perhatian/Atensi

- Faktor eksternal penarik perhatian

- Faktor internal penaruh perhatian

- Faktor sosiopsikologis

2. Faktor fungsional

- Kerangka rujukan

3. Faktor-faktor struktural

- konteks

- Kedekatan/persamaan

1. Pengetahuan mengenai netiket

2. Penerapan netiket di jejaring sosial, microblogging, serta forum

Ada pun yang menjadi batasan dalam penelitian ini, adalah:

1. Penelitian ini terbatas pada penerapan netiket di jejaring sosial facebook, microblogging Twitter, serta Forum di media siber seperti Detik Forum, dan ebagainya.

2. Responden dalam penelitian ini adalah mahasiswa/i FISIP USU, angkatan 2010, dan 2011. 


\section{Tinjauan Pustaka}

Penelitian mengenai pedoman perilaku di dunia maya (netiquette) sudah banyak dilakukan, antara lain yang dilakukan oleh Matti Tedre, Minna Kamppuri, dan Piet Kommers, yang berjudul An Approach To Global Netiquette Research. Mereka melihat bagaimana latar belakang budaya yang berbeda dari para pengguna internet mempengaruhi cara pandang mereka mengenai persoalan di dunia maya, seperti: aturan internet, tanggung jawab pengguna, permasalahan hak cipta, isu anonimitas, dan sebagainya. Ketiga peneliti tersebut menggunakan pendekatan kualitatif dengan metode antropologi. Tujuan dari penelitian ini adalah untuk menemukan seperangkat aturan yang umum bagi pengguna internet. Kesimpulan dalam penelitian ini adalah bahwa pedoman tingkah laku di dunia maya yang bersifat global sangat dibutuhkan. Netiket yang bersifat global tersebut merupakan landasan yang dapat digunakan oleh stakeholders dan berlaku untuk beragam budaya di berbagai negara dan kawasan (cs.joensuu.fi/pages/int/pub/tedre06.pdf).

Selain itu, terdapat penelitian lainnya yang dilakukan oleh Dr. Wan Norbani Wan Noordin, Dr. Massila Hamzah dengan judul Netiquette Practises in Malaysia: A Behavioral and Regulations on Human Online Interactions. Kedua peneliti ini juga merujuk ke penelitian sebelumnya yang juga menggunakan pedoman netiket yang dikemukakan oleh Virginia Shea. Tujuan dari penelitian ini adalah untuk menetapkan panduan netiket bagi mahasiswa di Malaysia.

\section{Netiquette (Netiket)}

Etiket adalah aturan perilaku di dalam kehidupan kita sehari-hari. Istilah etiket berasal dari kata dalam bahasa Perancis, yaitu etiquette yang artinya surat undangan beserta tata aturan yang termuat di dalam undangan tersebut. Etiket atau tata sopan santun ini biasanya merupakan hasil kesepakatan bersama di masyarakat tertentu, yang menjadi norma dalam mengatur tingkah laku anggota masyarakat tersebut (Darmastuti, 2007:41).

Salah satu sifat dari etiket adalah relatif. Relatif di sini artinya apa yang dianggap baik di suatu tempat belum tentu baik juga di tempat lainnya. Selain itu, etiket hanya berlaku dalam pergaulan. Jika ada orang yang hadir maka etiket berlaku, dan jika tidak ada orang yang hadir maka etiket tidak berlaku. Bisa jadi inilah yang menyebabkan ketika berseluncur di dunia maya, di mana tidak ada kehadiran orang lain secara fisik, maka pengguna internet seringkali lupa untuk menjaga sopan santun atau etiket. 
Padahal saat kita berkomunikasi di dunia maya, aturan itu tetap ada. Conrad (dalam Floyd, 2012:27) menemukan bahwa aturan/netiket yang mendapat perhatian lebih dari mahasiswa, yaitu:

- Be nice: berkomunikasi dengan sopan dan penuh hormat terhadap orang lain dengan cara memilih kata-kata yang akan diucapkan secara hati-hati.

- Conduct conflict privately: jika kita berkonflik dengan orang lain, jangan lakukan di forum publik. Namun, diskusikan persoalan tersebut lewat jalur pribadi, seperti $e$-mail misalnya.

- Show support: membantu orang lain dengan cara mendukung mereka dengan cara memberikan respon/saran atas postingan mereka, terutama mereka yang selama ini kurang mendapat perhatian.

- Use silence to reduce negativity: kita sering menjumpai seseorang berkomunikasi secara negatif di dunia maya. Namun, selayaknyalah kita tidak menanggapi dengan cara yang negatif pula. Lebih baik kita diam sejenak hingga situasi negatif tersebut reda.

Jadi, netiket adalah etika di dunia maya. Netiket merupakan seperangkat aturan untuk berperilaku di dunia maya. Virginia Shea menyebutkan aturan-aturan tersebut, yaitu:

1. Remember the human: bagaimana kita ingin diperlakukan oleh orang lain, begitu pula kita memperlakukan orang lain. Jadi, misalnya jika kita tidak ingin disakiti oleh komentarkomentar orang lain yang berbau SARA, maka kita juga jangan menuliskan pendapatpendapat yang menyinggung suku agama maupun ras orang lain.

2. Adhere to the same standards of behavior online that you follow in real life: kita harus menaati peraturan di dunia maya, seperti kita taat aturan di kehidupan nyata.

3. Know where you are in cyberspace: kita harus tahu bahwa kita bukan berada di dunia nyata. Ketika berada di dunia maya, apa yang kita lontarkan saat itu juga bisa tersebar ke banyak orang lain dan bisa dilihat oleh siapa saja di belahan bumi ini.

4. Respect other people's time and bandwidth: di sini dicontohkan jika kita mengirimkan sesuatu, kita harus meminta ijin terlebih dahulu. Karena hal itu bisa mengambil waktu mereka untuk mengunduh, membaca/melihat, dan bisa saja apa yang dikirimkan itu rentan akan virus. 
5. Make yourself look good online: cara orang berbicara, pemilihan kata biasanya menunjukkan siapa orang itu. Menjaga sopan santun dan memilih kata-kata yang pantas merupakan salah satu cara untuk membuat image yang baik di dunia maya.

6. Share expert knowledge: ketika berada di jejaring sosial, microblogging, dan forum, ada baiknya anda membagikan pengetahuan anda kepada semua teman-teman anda dan orang lain.

7. Help keep flame wars under control: jika ada perselisihan di forum, bertindaklah sebagai penengah, jangan sampai perselisihan di forum berlanjut lama, luas dan bahkan berlanjut di dunia nyata.

8. Respect other people's privacy: jangan membicarakan rahasia seseorang di dunia maya, karena itu melanggar privasi mereka dengan membeberkannya di ranah publik. Pengguna internet harus tahu dan paham mana yang ranah privat dan publik.

9. Don't abuse your power: jika anda memiliki kemampuan yang melebihi orang lain, jangan salah gunakan kemampuan tersebut. Misalkan, anda menggunakan kemampuan anda dalam memecahkan kode-kode biner untuk membajak akun seseorang, atau bisa juga membajak e-mailnya.

10. Be forgiving of other people's mistakes: semua orang pernah berbuat salah, entah itu menyinggung anda dengan komentarnya. Namun, memafkan lebih bijak, karena anda juga memiliki kemungkinan untuk berbuat salah terhadap orang lain (http://www.albion.com/netiquette/introduction.html).

\section{Persepsi}

Kata persepsi berasal dari bahasa latin, yaitu percipere yang artinya menerima atau mengambil. Persepsi terjadi di dalam pengamatan seseorang terhadap sesuatu dan bagaimana ia mengartikan sesuatu tersebut (Sobur, 2003).

Persepsi tidak muncul begitu saja. Ada faktor-faktor yang memengaruhi munculnya persepsi, yaitu:

1) Faktor Fungsional

Faktor Fungsional berasal dari kebutuhan, pengalaman masa lalu, dan hal-hal lain yakni apa yang kita sebut sebagai faktor personal. Penentu persepsi bukanlah bentuk stimuli, namun karakteristik orang yang memberikan respon pada stimuli tersebut. Menurut Krech 
dan Crutchfield, persepsi bersifat selektif. Ini berarti bahwa obyek-obyek yang mendapat tekanan dalam persepsi kita biasanya adalah obyek-obyek yang memenuhi tujuan seseorang dalam melakukan persepsi.

2) Faktor Struktural

Faktor struktural berasal dari sifat stimuli fisik dan efek-efek saraf yang ditimbulkannya pada sistem saraf individu. Menurut Krech dan Crutchfield, medan perseptual dan kognisi selalu diorganisasikan dan diberi arti.

3) Faktor Situasional

Faktor ini banyak berkaitan dengan bahasa non verbal. Bahasa non verbal terdiri dari: proksemik, kinesik, mimik wajah, dan paralinguistik.

4) Faktor Personal

Faktor personal terdiri atas pengalaman, motivasi, dan kepribadian. Pengalaman seseorang bertambah seiring dengan peristiwa-peristiwa yang dialaminya. Motivasi adalah faktor yang memengaruhi stimuli yang akan diproses. Sementara itu, kepribadian adalah polapola tingkah laku dan pikiran yang biasanya tetap dan menjadi karakteristik seseorang (Rakhmat, 2001).

Selain itu, ada pula yang mengatakan bahwa persepsi merupakan proses internal yang memungkinkan manusia memilih, mengorganisasikan, dan menafsirka rangsangan yang diterimanya dari lingkungan sekitar. Proses persepsi pada akhirnya memengaruhi perilaku manusia tersebut (Mulyana, 2005).

1) Proses menerima rangsangan: data-data atau stimuli kita terima dari lingkungan dengan menggunakan panca indera. Kita melihat, mendengar sesuati, mencium, merasakan dan menyentuhnya, sehingga kita mempelajari sesuatu tersebut.

2) Proses menyeleksi rangsangan: tidak semua rangsangan bisa kita terima. Kita melakukan seleksi atau penyaringan dari sekian banyak rangsangan, yang mana yang akan kita ambil untuk diproses lebih lanjut.

3) Proses pengorganisasian: setelah rangsangan diterima, maka rangsangan akan diorganisasikan dalam sebuah bentuk. Ada tiga (3) dimensi dalam pengorganisasian, yaitu: pengelompokkan (kita mengelompokkan rangsangan ke dalam suatu bentuk), bentuk timbul dan datar (dalam melihat rangsangan kita cenderung memusatkan pada rangsanganrangsangan yang timbul menonjol, sedangkan yang lain berada di latar belakang), 
kemantapan persepsi (kencederungan menstabilkan persepsi dan perubahan konteks tidak memengaruhinya).

4) Proses penafsiran: setelah rangsanga diterima dan diatur, maka kemudian si penerima akan menafsirkan rangsangan atau data itu dengan berbagai macam cara. Pada dasarnya persepsi adalah memberikan arti pada berbagai data yang diterima.

5) Proses pengecekan: setelah data diterima dan ditafsirkan maka si penerima kemudian akan mengambil tindakan untuk memeriksa benar atau tidaknya penafsirannya tadi. Proses ini berlangsung sangat cepat sehingga manusia kadang tidak menyadarinya.

6) Proses reaksi: merupakan tahap akhir di mana ini berupa tindakan yang berkaitan dengan apa yang telah ia serap sebelumnya. Hal ini terjadi ketika seseorang bertindak sehubungan dengan persepsinya (Sobur, 2003)

\section{Metodologi}

Penelitian ini menggunakan metode deskriptif. Metode deskriptif adalah metode yang ditujukan guna melakukan pengukuran yang cermat terhadap fenomena sosial tertentu. Metode ini mengembangkan konsep dan menghimpun fakta, namun tidak melakukan pengujian hipotesis (Singarimbun, 1995).

Teknik Pengumpulan Data

Teknik pengumpulan data yang digunakan dalam penelitian ini adalah sebagai berikut:

- $\quad$ Angket/kuesioner sebagai data primer yang merupakan daftar sejumlah pernyataan yang tertulis dan terstruktur dan disertai jawaban alternatif, yang akan disebarkan kepada sejumlah responden, yang berasal dari departemen-departemen yang terdapat di FISIP Universitas Sumatera Utara.

- Observasi yang dilakukan melalui pengamatan di dunia maya (facebook, twitter, maupun forum).

- Studi kepustakaan guna memperoleh informasi dan data-data dari sumber ilmah seperti buku, jurnal, dan lain sebagainya. 


\section{Teknik Analisis Data}

Penelitian ini menggunakan dua teknik analisis data, yaitu: Teknik analisis deskriptif. Analisis ini dilakukan untuk memberikan gambaran mengenai latar belakang responden dan memaparkan data-data perhitungan statistik responden berdasarkan perhitungan statistik yang telah dikelompokkan dan ditabulasikan.

\section{Populasi dan Sampel}

Sugiyono (dalam Kriyantono, 2007:149) menyebut populasi sebagai wilayah generalisasi yang terdiri dari obyek atau subyek yang memiliki kuantitas serta karakteristik tertentu yang ditetapkan oleh periset untuk dipelajari. Dalam penelitian ini yang menjadi populasi adalah keseluruhan mahasiswa/I FISIP USU baik untuk angkatan 2010, dan 2011.

\section{Tabel 1. Populasi}

\begin{tabular}{|c|c|c|c|}
\hline No. & \multicolumn{2}{|c|}{ Departemen } & Populasi \\
\hline \multirow{2}{*}{1.} & \multirow{2}{*}{ Sosiologi } & 2010 & 88 \\
\hline & & 2011 & 83 \\
\hline \multirow{2}{*}{2.} & \multirow{2}{*}{$\begin{array}{c}\text { Kesejahteraan } \\
\text { Sosial }\end{array}$} & 2010 & 91 \\
\hline & & 2011 & 98 \\
\hline \multirow{2}{*}{3.} & \multirow{2}{*}{$\begin{array}{l}\text { Administrasi } \\
\text { Negara }\end{array}$} & 2010 & 110 \\
\hline & & 2011 & 128 \\
\hline \multirow{2}{*}{4.} & \multirow{2}{*}{ Ilmu Komunikasi } & 2010 & 135 \\
\hline & & 2011 & 122 \\
\hline \multirow{2}{*}{5.} & \multirow{2}{*}{ Antropologi } & 2010 & 70 \\
\hline & & 2011 & 57 \\
\hline \multirow{2}{*}{6.} & \multirow{2}{*}{ Ilmu Politik } & 2010 & 99 \\
\hline & & 2011 & 84 \\
\hline \multirow[t]{3}{*}{7.} & \multirow{2}{*}{$\begin{array}{l}\text { Adm. Niaga } \\
\text { Bisnis }\end{array}$} & 2010 & 110 \\
\hline & & 2011 & 137 \\
\hline & \multicolumn{2}{|c|}{ Total } & 1412 \\
\hline
\end{tabular}

Sampel yaitu sebagian dari keseluruhan obyek atau fenomena yang akan diamati. Dengan kata lain, sampel adalah sebagian dari obyek penelitian yang dipilih dan dianggap mewakili secara keseluruhan. Teknik penarikan sampel yang digunakan adalah teknik penarikan sampel proporsional dan purposive sampling.

Penentuan jumlah sampel dari populasi mengggunakan tabel dari Krejcie dan Morgan 1970 dengan taraf kepercayaan 95\%. Dari tabel tersebut, untuk jumlah anggota populasi sebesar 1400, maka jumlah anggota sampel sebesar 302. Karena populasi dalam penelitian ini sebesar 1412 maka $\approx 1400$, dan sampel penelitian menjadi 302 . 


\section{- Proportional Stratified Sampling}

Teknik ini digunakan karena dalam penelitian ini sampel bersifat heterogen dengan karakteristik yang bervariasi. Selain itu teknik ini digunakan karena populasi yang akan dijadikan sampel terdiri dari beberapa departemen dan stambuk yaitu 2010-2011. Dengan menggunakan teknik ini, maka sampel yang dihasilkan dari tiap-tiap departemen sebagai berikut:

Tabel 2. Proportional Stratified Sampling

\begin{tabular}{|c|c|c|c|c|}
\hline No. & \multicolumn{2}{|l|}{ Departemen } & Populasi & Sampel \\
\hline \multirow{2}{*}{1.} & \multirow{2}{*}{ Sosiologi } & 2010 & 88 & $\frac{88}{1412} \times 302=18,82 \approx 19$ \\
\hline & & 2011 & 83 & $\frac{83}{1412} \times 302=17,75 \approx 18$ \\
\hline \multirow{2}{*}{2.} & \multirow{2}{*}{ Kesejahteraan Sosial } & 2010 & 91 & $\frac{91}{1412} \times 302=19,46 \approx 19$ \\
\hline & & 2011 & 98 & $\frac{98}{1412} \times 302=20,96 \approx 21$ \\
\hline \multirow{2}{*}{3.} & \multirow{2}{*}{$\begin{array}{l}\text { Administrasi } \\
\text { Negara }\end{array}$} & 2010 & 110 & $\frac{110 \times}{1412} 302=23,52 \approx 24$ \\
\hline & & 2011 & 128 & $\frac{128}{1412} \times 302=27,36 \approx 27$ \\
\hline \multirow{2}{*}{4.} & \multirow{2}{*}{ Ilmu Komunikasi } & 2010 & 135 & $\frac{135}{1412} \times 302=28,87 \approx 29$ \\
\hline & & 2011 & 122 & $\frac{122}{1412} \times 302=26,09 \approx 26$ \\
\hline \multirow{2}{*}{5.} & \multirow{2}{*}{ Antropologi } & 2010 & 70 & $\frac{70}{1412} \times 302=14,97 \approx 15$ \\
\hline & & 2011 & 57 & $\frac{57}{1412} \times 302=12,19 \approx 12$ \\
\hline \multirow{2}{*}{6.} & \multirow{2}{*}{ Ilmu Politik } & 2010 & 99 & $\frac{99}{1412} \times 302=21,17 \approx 21$ \\
\hline & & 2011 & 84 & $\frac{84}{1412} \times 302=17,96 \approx 18$ \\
\hline \multirow[t]{3}{*}{7.} & \multirow[t]{2}{*}{ Adm. Niaga Bisnis } & 2010 & 110 & $\frac{110}{1412} \times 302=23,52 \approx 24$ \\
\hline & & 2011 & 137 & $\frac{137}{1412} \times 302=29,30 \approx 29$ \\
\hline & \multicolumn{2}{|l|}{ Total } & 1412 & 302 \\
\hline
\end{tabular}

\section{- Purposive Sampling}

Teknik yang disesuaikan dengan tujuan penelitian, dimana sampel yang digunakan sesuai dengan kriteria-kriteria tertentu yang ditetapkan berdasarkan tujuan penelitian (Kriyantono, 2006:154).

Adapun kriteria sampel yang dimaksud dalam penelitian ini adalah:

- Mahasiswa FISIP USU yang memiliki akun facebook, twitter, dan pernah menuliskan komentar di forum situs berita seperti Detik.

- Mahasiswa FISIP USU angkatan 2010 dan 2011. 


\section{Kelemahan dan Keterbatasan Penelitian}

Hasil dari penelitian ini berupa deskripsi dalam bentuk angka-angka (persentase). Hal ini tentu saja tidak bisa memberikan penjelasan yang lebih dalam mengenai pemahaman dan penerapan responden atas netiket.

Jawaban yang diberikan atas pertanyaan-pertanyaan di kuesioner bisa saja bias karena sulit mengukur kejujuran seseorang ketika ditanyakan apakah ia melakukan sesuatu yang salah menurut norma/aturan. Kelemahan ini bisa diatasi dengan menggunakan pendekatan penelitian yang berbeda, di mana metode pengumpulan data dengan menggunakan teknik wawancara mendalam. Dari teknik tersebut bisa dilihat konsistensi jawaban informan atas pertanyaanpertanyaan yang berkaitan dengan etiket (netiket).

Selain itu, keterbatasan yang datang dari diri peneliti adalah kurang dalam melakukan pra riset. Jika pada saat pra riset bisa diperoleh data yang pasti mengenai mahasiswa yang memiliki dan aktif dalam menggunakan situs jejaring sosial (facebook, twitter, dan meninggalkan komentar di forum berita online), maka responden penelitian bisa dipilih secara acak, sehingga penelitian akan lebih obyektif.

\section{Hasil dan Pembahasan}

Dari beberapa pertanyaan yang berkaitan dengan hal demografis, ditemukan bahwa sebanyak 186 responden (61,6\%) memiliki pengeluaran antara 500.000-1.000.000 per bulan, 70 responden $(23,2 \%)$ memiliki pengeluaran $<500.000$ per bulan. Selain itu, terdapat 38 responden $(12,6 \%)$ memiliki pegeluaran antara 1.000.000-1.500.000 per bulan. Dan 8 orang responden $(2,6 \%)$ yang memiliki pengeluaran $>1.500 .000$. Data ini menggambarkan bahwa mahasiswa FISIP USU rata-rata berada pada golongan menengah ke atas.

Gambaran mengenai kepemilikan akun di jejaring sosial, microblogging, blog dan forum tampak seperti pada tabel 3. Dari tabel kepemilikan akun pada table tersebut, tampak bahwa Facebook dan Twitter adalah situs jejaring sosial dan microblogging yang paling banyak dimiliki oleh mahasiswa FISIP USU. Sebagai catatan, Indonesia merupakan negara peringkat keempat yang memiliki pengguna akun Facebook terbanyak di dunia. Hanya sedikit mahasiswa yang memiliki akun di LingkedIn (4 orang). Hal ini mungkin lebih dikarenakan situs tersebut bersifat sedikit lebih serius, karena tempat berkumpulnya para profesional dari berbagai macam bidang pekerjaan. 
Tabel 3. Kepemilikan Akun Jejaring Sosial, Blog, Microblogging, Berita Online, dsb.

\begin{tabular}{|l|c|c|c|}
\hline \multicolumn{1}{|c|}{ Akun } & Punya & Tidak Punya & Total \\
\hline Facebook & 291 & 11 & $\mathbf{3 0 2}$ \\
\hline Twitter & 249 & 53 & $\mathbf{3 0 2}$ \\
\hline MySpace & 52 & 250 & $\mathbf{3 0 2}$ \\
\hline LinkedIn & 4 & 298 & $\mathbf{3 0 2}$ \\
\hline Blog & 90 & 212 & $\mathbf{3 0 2}$ \\
\hline Kaskus & 49 & 253 & $\mathbf{3 0 2}$ \\
\hline Kompas.com & 46 & 256 & $\mathbf{3 0 2}$ \\
\hline Detik.com & 51 & 251 & $\mathbf{3 0 2}$ \\
\hline YouTube & 106 & 196 & $\mathbf{3 0 2}$ \\
\hline Hi5 & 10 & 292 & $\mathbf{3 0 2}$ \\
\hline Koprol & 19 & 283 & $\mathbf{3 0 2}$ \\
\hline
\end{tabular}

Sumber: P. 6/FC. 6-16

Adapun gambaran mengenai fasilitas yang digunakan oleh responden untuk berselancar di dunia maya adalah sebagai berikut:

Tabel 4. Fasilitas yang Digunakan untuk Berselancar di Dunia Maya

\begin{tabular}{|l|c|c|c|}
\hline \multicolumn{1}{|c|}{ Fasilitas } & Ya & Tidak & Total \\
\hline Laptop dan Wifi Gratis & 195 & 107 & $\mathbf{3 0 2}$ \\
\hline Laptop Pribadi \& Modem Pribadi & 215 & 87 & $\mathbf{3 0 2}$ \\
\hline Smartphone & 163 & 139 & $\mathbf{3 0 2}$ \\
\hline Warnet & 165 & 137 & $\mathbf{3 0 2}$ \\
\hline Lainnya (mis: pinjam BB teman) & 1 & 301 & $\mathbf{3 0 2}$ \\
\hline
\end{tabular}

Sumber: P. 7/ FC. 18-22

Dari tabel di atas bisa dilihat bahwa hampir sebagian besar mahasiswa yang menjadi responden dalam penelitian ini, menggunakan laptop pribadi dan modem pribadi untuk berselancar di dunia maya. Ini tampak sesuai dengan kondisi pengeluaran yang dimiliki oleh mahasiswa per bulannya.

Hasil pengolahan data deskriptif menggunakan piranti SPSS menunjukkan bahwa masih banyak mahasiswa FISIP USU angkatan 2010 dan 2011 yang belum pernah mendengar dan mengetahui apa itu netiket. Ketika di awal pertanyaan kuesioner, responden dipancing dengan pertanyaan mengenai perlu atau tidaknya etika dalam pergaulan sehari-hari, sebagian besar responden, yaitu 239 orang menyatakan sangat perlu, dan 61 orang menyatakan perlu diterapkannya etika.

Dari 302 orang responden, hanya 47 orang (15.6\%) yang pernah mendengar istilah netiket. Dan dari 47 orang tersebut, hanya 37 orang yang dengan tepat menjawab apa itu netiket. Hal ini merupakan gambaran bahwa sebagai netizen, mahasiswa FISIP USU angkatan 2010 dan 2011 
belum aware dengan norma-norma yang sebenarnya juga ada dan berlaku di dunia maya, selayaknya di dunia nyata.

Ketika diberikan pertanyaan-pertanyaan di mana para responden disuruh untuk mengingat kembali apa yang mereka lihat/temukan baik itu di jejaring sosial maupun di situs berita online, maka hasilnya seperti yang tampak pada tabel di bawah ini.

Tabel 5. Melihat/Menemukan Sesuatu di Jejaring Sosial

\begin{tabular}{|c|c|c|c|c|c|}
\hline Peristiwa & Selalu & Sering & Jarang & $\begin{array}{c}\text { Tidak } \\
\text { Pernah }\end{array}$ & Total \\
\hline Komentar yang berbau SARA. & 19 & 108 & 143 & 32 & 302 \\
\hline $\begin{array}{l}\text { Pengguna menaati aturan seperti di Dunia nyata, mis: } \\
\text { memanggil } \mathrm{Pak} / \mathrm{Bu} / \mathrm{Kak} / \mathrm{dsb} \text {. }\end{array}$ & 49 & 106 & 129 & 18 & 302 \\
\hline Pengguna menyebarkan hoax/kebohongan. & 11 & 134 & 126 & 31 & 302 \\
\hline Pengguna mem-posting iklan ke dinding orang lain tanpa ijin. & 26 & 153 & 90 & 33 & 302 \\
\hline Pengguna menggunakan kata-kata yang santun. & 29 & 145 & 125 & 3 & 302 \\
\hline $\begin{array}{l}\text { Pengguna membagikan pengetahuan baru kepada teman- } \\
\text { temannya. }\end{array}$ & 29 & 191 & 79 & 3 & 302 \\
\hline Pengguna menjadi penengah saat ada perselisihan. & 11 & 96 & 157 & 38 & 302 \\
\hline Pengguna membocorkan rahasia temannya. & 9 & 102 & 128 & 63 & 302 \\
\hline Pengguna membajak akun orang lain untuk kepentingan pribadi. & 17 & 134 & 96 & 55 & 302 \\
\hline $\begin{array}{l}\text { Sesama pengguna tidak mau saling memaafkan setelah perang } \\
\text { komentar }\end{array}$ & 9 & 99 & 135 & 59 & 302 \\
\hline
\end{tabular}

Sumber: P. 17/FC. 32-41

Dari tabel di atas, lebih banyak responden yang 'Jarang' serta 'Tidak Pernah' melihat pengguna lain yang menuliskan komentar berbau SARA daripada responden yang 'Sering' ataupun 'Selalu' melihat. Selain itu, sebagian besar responden menyatakan bahwa banyak pengguna jejaring sosial yang menyebarkan iklan ke dinding orang lain tanpa seijin si empunya. Ini bisa terlihat dari semakin banyaknya orang yang memanfaatkan Facebook sebagai arena tempat berjualan/berbisnis.

Hal yang positif adalah, bahwa sebagian besar responden menyatakan bahwa mereka melihat banyak pengguna yang berbicara dengan menggunakan kata-kata yang santun. Namun, banyak dari responden yang jarang ataupun tidak pernah melihat orang lain menjadi penengah saat terjadi perang komentar di jejaring sosial. 
Tabel 6. Temuan Saat Membaca Komentar di Situs Berita Online

\begin{tabular}{|l|c|c|c|c|c|}
\hline \multicolumn{1}{|c|}{ Peristiwa } & Selalu & Sering & Jarang & Tidak Pernah & Total \\
\hline Komentar yang berbau SARA. & 10 & 114 & 150 & 28 & $\mathbf{3 0 2}$ \\
\hline $\begin{array}{l}\text { Komentator menaati aturan seperti di Dunia } \\
\text { nyata, mis: memanggil Pak/Bu/Kak/dsb. }\end{array}$ & 33 & 133 & 123 & 13 & $\mathbf{3 0 2}$ \\
\hline $\begin{array}{l}\text { Komentator menyebarkan } \\
\text { hoax/kebohongan. }\end{array}$ & 13 & 116 & 136 & 35 & $\mathbf{3 0 2}$ \\
\hline $\begin{array}{l}\text { Komentator mem-posting iklan tanpa seijin } \\
\text { oranglain. }\end{array}$ & 21 & 149 & 98 & 34 & $\mathbf{3 0 2}$ \\
\hline $\begin{array}{l}\text { Komentator menggunakan kata-kata yang } \\
\text { santun. }\end{array}$ & 27 & 153 & 114 & 8 & $\mathbf{3 0 2}$ \\
\hline $\begin{array}{l}\text { Komentator membagikan pengetahuan baru } \\
\text { kepada teman-temannya. }\end{array}$ & 29 & 191 & 79 & 3 & $\mathbf{3 0 2}$ \\
\hline $\begin{array}{l}\text { Komentator menjadi penengah saat ada } \\
\text { perselisihan. }\end{array}$ & 17 & 104 & 150 & 31 & $\mathbf{3 0 2}$ \\
\hline $\begin{array}{l}\text { Komentator membocorkan rahasia } \\
\text { temannya. }\end{array}$ & 8 & 73 & 150 & 71 & $\mathbf{3 0 2}$ \\
\hline $\begin{array}{l}\text { Komentator yang merasa lebih tahu, } \\
\text { memojokkan orang lain. }\end{array}$ & 16 & 93 & 140 & 53 & $\mathbf{3 0 2}$ \\
\hline $\begin{array}{l}\text { Sesama komentator tidak mau saling } \\
\text { memaafkan setelah perang komentar }\end{array}$ & & 120 & 120 & 44 \\
\hline
\end{tabular}

Sumber: P. 18/FC. 42-51

Dari tabel di atas dapat dilihat bahwa hanya sedikit perbedaan antara jumlah responden yang menyatakan 'Selalu' dan 'Sering' melihat orang berkomentar yang menyinggung SARA di berita online, dengan jumlah responden yang menyatakan 'Jarang' ataupun 'Tidak Pernah' melihat. Hal lain yang perlu dicatat adalah banyaknya orang yang menyebarkan iklan di kolom komentar berita online. Total 170 responden yang menyatakan 'Selalu' dan 'Sering' melihat orang menyebarkan iklan tanpa seijin orang lain.

Hal positif yang bisa dilihat yaitu, responden menyatakan 'Selalu' maupun 'Sering' melihat orang membagikan pengetahuan baru di kolom komentar tersebut. Serta banyak responden yang menyatakan bahwa komentator 'Selalu' maupun 'Sering' menggunakan kata-kata yang santun saat menuliskan komentarnya.

Namun, terdapat total 181 responden yang menyatakan 'Jarang' dan 'Tidak Pernah' menyaksikan komentator menjadi penengah saat terjadi perang komentar. Serta, 193 responden menyatakan 'Jarang' dan 'Tidak Pernah' melihat komentator mau saling memaafkan setelah terjadi perang komentar. Memang, jika kita memerhatikan kolom komentar di berita online. Perang komentar seringkali tidak selesai dan berlanjut di kolom komentar berita terkait lainnya.

Gambaran yang sama juga ditemukan saat hal tersebut ditanyakan ke diri mereka sendiri. Sebagaian besar responden masih 'Jarang' ataupun 'Tidak Pernah' menjadi penengah ketika perang komentar terjadi di jejaring sosial maupun di kolom komentar berita online. Namun, 
secara keseluruhan para responden menyatakan 'Sangat Setuju' (185 orang) dan 'Setuju' (113 orang) bahwa para netizen sebaiknya menerapkan netiket selama berinteraksi di dunia maya.

Tabel 7. Pernah Melakukan Hal-hal Berikut Saat Berselancar di Jejaring Sosial

\begin{tabular}{|l|c|c|c|c|c|}
\hline \multicolumn{1}{|c|}{ Peristiwa } & Selalu & Sering & Jarang & Tidak Pernah & Total \\
\hline Menulis komentar yang berbau SARA. & 6 & 29 & 111 & 156 & $\mathbf{3 0 2}$ \\
\hline $\begin{array}{l}\text { Menerapkan aturan seperti di Dunia nyata, } \\
\text { mis: memanggil Pak/Bu/Kak/dsb. }\end{array}$ & 69 & 128 & 88 & 17 & $\mathbf{3 0 2}$ \\
\hline Menyebarkan hoax/kebohongan. & 4 & 27 & 83 & 188 & $\mathbf{3 0 2}$ \\
\hline $\begin{array}{l}\text { Mem-posting iklan ke dinding orang lain } \\
\text { tanpa ijin. }\end{array}$ & 8 & 33 & 79 & 182 & $\mathbf{3 0 2}$ \\
\hline Menggunakan kata-kata yang santun. & 77 & 163 & 56 & 6 & $\mathbf{3 0 2}$ \\
\hline $\begin{array}{l}\text { Membagikan pengetahuan baru kepada } \\
\text { teman-teman. }\end{array}$ & 33 & 125 & 132 & $\mathbf{3 0 2}$ \\
\hline Menjadi penengah saat ada perselisihan. & 18 & 77 & 149 & 58 & $\mathbf{3 0 2}$ \\
\hline Membocorkan rahasia temannya. & 4 & 21 & 58 & 219 & $\mathbf{3 0 2}$ \\
\hline $\begin{array}{l}\text { Membajak akun orang lain untuk } \\
\text { kepentingan pribadi. }\end{array}$ & 5 & 26 & 62 & 209 & $\mathbf{3 0 2}$ \\
\hline $\begin{array}{l}\text { Tidak mau saling memaafkan setelah perang } \\
\text { komentar }\end{array}$ & 8 & 28 & 73 & & 193 \\
\hline
\end{tabular}

Sumber: P. 19/ FC. 52-61

Dari tabel di atas dapat dijelaskan bahwa sebagian besar responden (167 orang) menyatakan jarang dan tidak pernah menulis komentar yang menyinggung SARA di jejaring sosial, serta merekapun menerapkan aturan di dunia nyata seperti menggunakan panggilan 'Pak', 'Bu', ataupun 'Kak' ketika berbicara dengan yang lebih tua. Sebagian besar dari mereka juga jarang dan tidak pernah menyebarkan iklan ke dinding orang lain.

Adapun beberapa responden yang menuliskan komentar yang menyinggung SARA, dalam hal ini agama, tidak lain karena mereka membalas status teman mereka yang menyinggung agama tertentu. Misalnya ketika teman mereka mem-posting berita mengenai tiga pemain Timnas Perancis yang kepergok mengencani pekerja seks komersil di bawah umur, dan disertai dengan komentar yang menyinggung agama. Lantas, responden tersebut membalas dengan menyinggung tingkah laku pemain bola lainnya yang berbeda agama, yang ia anggap juga menyimpang.

Dari tabel 8 diperoleh hasil bahwa sebagian besar responden (257 orang) menyatakan jarang dan tidak pernah menulis komentar yang menyinggung SARA di kolom komentar berita online. Responden yang menuliskan komentar SARA biasanya karena mereka melihat ada pengguna lain yang terlebih dahulu menyinggung agama mereka. Sebagian besar dari mereka juga jarang ataupun tidak pernah menyebarkan hoax maupun iklan 
Sebagian besar responden juga selalu maupun sering menggunakan kata-kata yang sopan saat menuliskan komentar di situs berita online. Namun, sebagian besar dari responden jarang maupun tidak pernah menjadi penengah apabila terjadi perang komentar di berita online.

Tabel 8. Melakukan Hal-hal Sebagai Berikut di Situs Berita Online

\begin{tabular}{|c|c|c|c|c|c|}
\hline Peristiwa & Selalu & Sering & Jarang & Tidak Pernah & Total \\
\hline Menulis komentar yang berbau SARA. & 7 & 38 & 69 & 188 & 302 \\
\hline $\begin{array}{l}\text { Menerapkan aturan seperti di Dunia nyata, } \\
\text { mis: memanggil } \mathrm{Pak} / \mathrm{Bu} / \mathrm{Kak} / \mathrm{dsb} \text {. }\end{array}$ & 73 & 129 & 74 & 26 & 302 \\
\hline Menyebarkan hoax/kebohongan. & 2 & 23 & 76 & 201 & 302 \\
\hline $\begin{array}{l}\text { Mem-posting iklan ke dinding orang lain } \\
\text { tanpa ijin. }\end{array}$ & 6 & 32 & 52 & 212 & 302 \\
\hline Menggunakan kata-kata yang santun. & 81 & 133 & 66 & 22 & 302 \\
\hline $\begin{array}{l}\text { Membagikan pengetahuan baru kepada } \\
\text { teman-teman. }\end{array}$ & 31 & 101 & 125 & 45 & 302 \\
\hline Menjadi penengah saat ada perselisihan. & 13 & 67 & 126 & 96 & 302 \\
\hline Membocorkan rahasia temannya. & 3 & 27 & 50 & 222 & 302 \\
\hline $\begin{array}{l}\text { Membajak akun orang lain untuk } \\
\text { kepentingan pribadi. }\end{array}$ & 2 & 25 & 53 & 222 & 302 \\
\hline $\begin{array}{l}\text { Tidak mau saling memaafkan setelah perang } \\
\text { komentar }\end{array}$ & 3 & 29 & 75 & 195 & 302 \\
\hline
\end{tabular}

Sumber: P. 20/FC. 62-71

\section{Kesimpulan dan Saran}

\section{Kesimpulan}

Hasil olah data menggunakan piranti SPSS akhirnya menjawab pertanyaan mengenai bagaimana persepsi mahasiswa FISIP USU mengenai netiket di dunia maya. Kesimpulan dari penelitian ini adalah sebagai berikut:

1) Sebagian besar responden (255 orang) tidak/belum pernah mendengar istilah netiket.

2) Dari 47 orang responden yang pernah mendengan istilah netiket, hanya 37 orang responden yang dengan tepat menjelaskan apa itu netiket.

3) Dari tujuh (7) jurusan yang terdapat di FISIP USU, responden yang berasal dari jurusan Administrasi Bisnis yang paling banyak menjawab dengan tepat apa itu netiket, yaitu berjumlah 11 orang responden.

4) Dari 20 pertanyaan yang ditujukan kepada responden mengenai apa yang mereka pernah lihat di jejaring sosial maupun berita online, mayoritas responden menjawab pelanggaran dalam bentuk mem-posting iklan ke dinding ataupun ke kolom komentar tanpa seijin pemilik akun maupun oranglain, yang paling banyak terjadi. 
5) Mayoritas responden menjawab sangat setuju (185 orang) dan setuju (113 orang) bahwa netizen perlu menerapkan netiket di dunia maya.

\section{Saran}

Saat seminar hasil diadakan, ada beberapa saran dari peserta seminar terhadap penelitian ini. Saran tersebut adalah sebagai berikut:

1) Penelitian ini bisa dilanjutkan untuk mengetahui lebih dalam mengenai penerapan ataupun pelanggaran netiket oleh para netizen. Penelitian selanjutnya bisa menggunakan pendekatan kualitatif, karena persoalan etika seringkali kurang tepat bila digambarkan dengan angka-angka.

2) Ada baiknya jika dilakukan pra-riset untuk mengetahui jumlah pasti mahasiswa yang memiliki akun di jejaring sosial, microblogging, maupun situs berita online, sehingga teknik penarikan sampel secara acak bisa dilakukan sehingga menambah tingkat obyektivitas penelitian. 


\section{Daftar Pustaka}

Consalvo, M., Ess, C. 2011. The Handbook of Internet Studies. Wiley-Blackwell.

Darmastuti, R. 2007. Etika PR dan E-PR. Yogyakarta: Gava Media.

Ess, C. 2009. Digital Media Ethics. Cambridge: Polity Press.

Floyd, K. 2012. Interpersonal Communication, Second Edition. New York: McGraw-Hill International Edition.

Kriyantono, R. 2007. Riset Komunikasi. Jakarta: Kencana

Mulyana, D. 2005. Ilmu Komunikasi Suatu Pengantar. Bandung: Remaja Rosdakarya

Singarimbun, M. 1995. Metode Penelitian Survey. Jakarta: LP3S

Sudibyo, A. 2012. Mengapa Perlu Pedoman Pemberitaan Media Siber. Disampaikan pada Seminar Sosialisasi Dewan Pers, Medan.

Sugiyono, Prof. Dr. 2004. Statistik Nonparametris Untuk Penelitian. Bandung: CV. Alvabeta.

Sobur, A. 2003. Psikologi Umum. Bandung: Pustaka Setia

\section{Jurnal}

An Approach to Global Netiquette Research. cs.joensuu.fi/pages/int/pub/tedre06.pdf. diunduh: 10 Juni 2012.

http://www.albion.com/netiquette/introduction.html. diunduh: Januari 2012

wcaweb.org/.../13\%20Wan\%20Norbani\%20...diunduh: 4 Juni 2012

\section{Situs Berita Online}

Hina Guru Lewat Facebook, 4 Siswa Kepri Dikeluarkan dari Sekolah.

http://news.detik.com/read/2010/02/14/143841/1299260/10/hina-guru-lewat facebook-4-siswakepri-dikeluarkan-dari-sekolah 
